\title{
TOXICITY OF PRE-EMERGENT HERBICIDES APPLIED VIA IRRIGATION WATER IN EUCALYPTUS PLANTATION
}

\author{
Aderson Costa Araujo Neto ${ }^{1 *}$, Alcebíades Rebouças São José , Eduardo de Souza Moreira ${ }^{1}$, Thiago Reis Prado ${ }^{1}$, \\ Maurício Robério Silva Soares ${ }^{2}$, Raelly da Silva Lima ${ }^{1}$

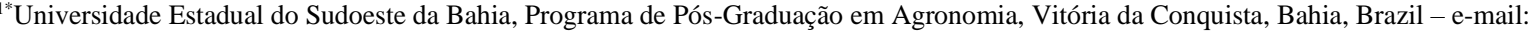 adersoncaneto@gmail.com; esmmoreira@gmail.com; thiago.agro@live.com; raellysilva@hotmail.com
${ }^{2}$ Universidade Estadual do Sudoeste da Bahia, Departamento de Fitotecnia e Zootecnia, Vitória da Conquista, Bahia, Brazil - e-mail: alreboucas@gmail.com; mauriciouesb@hotmail.com

Received for publication: 03/08/2018 - Accepted for publication: 04/06/2019

\begin{abstract}
Resumo
Toxicidade de herbicidas pré-emergentes veiculados à água de irrigação na implantação da cultura do eucalipto. Objetivou-se, com este trabalho, avaliar a toxicidade de herbicidas pré-emergentes às plantas de eucalipto e eficiência no controle de plantas daninhas, quando aplicados via água de irrigação na implantação da cultura. $\mathrm{O}$ experimento foi conduzido em condições de campo, utilizando-se para cada herbicida o delineamento experimental de blocos casualizados, em esquema bifatorial $5 \times 2$, com quatro repetições, considerando-se como fatores as cinco doses avaliadas dos herbicidas (isoxaflutole $-0 ; 75 ; 105 ; 135$ e $165 \mathrm{~g}$ i.a. ha ${ }^{-1}$; flumioxazin - 0; 70; 90; 110 e 130 g i.a. ha ${ }^{-1}$; sulfentrazone $-0 ; 400 ; 600 ; 800$ e 1000 g i.a. ha-1) e duas formas de aplicação (diretamente sobre a planta e somente sobre o solo). Os tratamentos foram aplicados manualmente 20 dias após o plantio das mudas com auxílio de um regador. Foram realizadas avaliações de porcentagem visual de intoxicação, altura de plantas, diâmetro do caule, índice de clorofila Falker, número de folhas, área foliar e massa seca da parte aérea das plantas de eucalipto. As plantas daninhas presentes na área útil do entorno das covas de plantio foram identificadas e quantificadas, para a determinação da densidade de plantas na área amostrada por tratamento. Constatou-se que apenas o sulfentrazone ocasionou sintomas de intoxicação às plantas, embora não influenciando no desenvolvimento do eucalipto. $\mathrm{O}$ isoxaflutole, independente da forma de aplicação, e o flumioxazin, aplicado diretamente sobre as plantas, mostraram-se seletivos à cultura, proporcionando nas maiores doses (165 e $130 \mathrm{~g}$ i.a. ha ${ }^{-1}$, respectivamente) eficiente controle das plantas daninhas e incremento no crescimento inicial do eucalipto.
\end{abstract}

Palavras-chave: Eucalyptus spp., controle químico, formas de aplicação, tolerância, fitointoxicação.

\begin{abstract}
The objective of this study was to evaluate the toxicity of pre-emergent herbicides to eucalyptus plants and weed control efficiency when applied via irrigation water in crop implementation. The experiment was conducted under field conditions, using the experimental randomized block design for each herbicide, in a $5 \mathrm{x}$ 2 bifactorial scheme, with four replications, considering the five evaluated herbicide doses as factors (isoxaflutole $-0 ; 75 ; 105 ; 135$ and $165 \mathrm{~g}$ i.a. ha- ${ }^{-1}$ flumioxazin $-0 ; 70 ; 90 ; 110$ and $130 \mathrm{~g}^{\text {i.a. ha }}$ h; $^{-1}$ sulfentrazone $-0 ; 400 ; 600 ; 800$ and $1000 \mathrm{~g}$ i.a. ha ${ }^{-1}$ ), besides two forms of application (directly on the plant and only on the soil). The treatments were applied manually 20 days after the seedlings were planted, using a watering can. Eucalyptus intoxication percentage, plant height, stem diameter, Falker chlorophyll index, leaf number, leaf area and shoot dry mass were evaluated. Weeds present in the useful area around the planting holes were identified and quantified to determine the plant density in the area sampled per treatment. It was found that only sulfentrazone caused plant intoxication symptoms, despite not influencing eucalyptus development. Isoxaflutole, regardless of application form, and flumioxazin, applied directly on the plants, were selective to the crop, providing at the highest doses (165 and 130 i.a. ha ${ }^{-1}$, respectively) efficient weed control and increment in initial eucalyptus growth.

Keywords: Eucalyptus spp., chemical control, forms of application, tolerance, phytointoxication.
\end{abstract}

\section{INTRODUCTION}

Eucalyptus (Eucalyptus sp.), in its diversity of species cultivated in Brazil, gained prominence in the national forest sector, with about 5.7 million hectares planted (IBÁ, 2017). The preference of forestry companies for eucalyptus planting is due to its rapid growth, high forest productivity and multiple uses of wood, as well as the availability of cultivation technologies and the improvement in silvicultural practices, including weed management (BARROS et al., 2014).

The occurrence of weeds in eucalyptus plantation areas impairs crop growth and development, due to competition for water, nutrients and light, especially in the early development period. During this period, competition may be intensified as a function of post-planting eucalyptus irrigation, frequently located in the hole 
rather than in the total area, which contributes to the growth of weeds close to the seedlings. To avoid damage, it is recommended to manage them before interference with the crop occurs (TAKAHASHI et al., 2009).

Weed management in forest areas, in the various stages of their production process, is basically performed by the use of mechanical and chemical methods, isolated or combined (PEREIRA et al., 2012). The chemical method is the most used, since it allows faster, more efficient and longer results. It also allows control of the weed community before or after its emergence (CARBONARI et al., 2010). Among the pre-emergent herbicides applied to the eucalyptus crop, isoxaflutole, flumioxazin and sulfentrazone stand out (TIBURCIO et al., 2012).

Isoxaflutole is a systemic herbicide and its mechanism of action is based on the inhibition of carotenoid synthesis. Once in soil, water and plant, it is rapidly converted to diquetonitrile, the biologically active molecule in weed control (SILVA et al., 2014). It effectively controls monocotyledons and some dicotyledons (SILVA; SILVA, 2007).

The mechanism of action of the herbicides sulfentrazone and flumioxazin is based on the inhibition of protoporphyrinogen oxidase (PROTOX) and has contact action with sprayed plants. Sulfentrazone effectively controls monocotyledons and dicotyledons (FERRAÇO et al., 2017), while flumioxazin can be applied pre- and postemergence for dicotyledonous weed control (RODRIGUES; ALMEIDA, 2011).

The forest sector has been seeking to improve herbicide application practices, aiming at efficiency, low environmental impact and reduction in production costs for the eucalyptus crop (COSTA et al., 2012). However, information about other forms of application of these herbicides, as well as the use of doses different from those recommended by manufacturers and their effects on the initial growth of eucalyptus seedlings, are scarce in the literature.

The cost of implementing eucalyptus plantations is quite high; the integration of necessary activities, such as post-planting irrigation and weed control, is therefore a way to reduce it. One possibility is, when opting for chemical control, to do so together with irrigation, since the seedlings need water supply to settle in the field, which favors weed emergence in the planting rows (SIMÕES; SILVA, 2012). Therefore, studies that focus on the effects of pre-emergence application of herbicides via irrigation water on the metabolism of eucalyptus plants are necessary.

In this context, the objective of this study was to evaluate the toxicity of the herbicides isoxaflutole, flumioxazin and sulfentrazone to eucalyptus plants and weed control efficiency when applied pre-emergence via irrigation water at the initial crop implementation phase.

\section{MATERIAL AND METHODS}

The experiment was carried out from October 2016 to January 2017, in the experimental area of Universidade Estadual do Sudoeste da Bahia, Vitória da Conquista Campus, BA, Brazil, located at $14^{\circ} 88^{\prime}$ South latitude and 40 $79^{\prime}$ 'West longitude, at an average altitude of $941 \mathrm{~m}$. According to the Köppen classification, the local climate is Cwa type (tropical in altitude), with an average annual rainfall of $741 \mathrm{~mm}$. According to data from the National Institute of Meteorology (INMET, 2016), the mean maximum and minimum temperatures obtained during the experimental period were $24.1^{\circ} \mathrm{C}$ and $19.5^{\circ} \mathrm{C}$, respectively. $76.2 \%$ relative humidity and cumulative rainfall of $232.4 \mathrm{~mm}$.

The soil of the experimental area was classified as Oxisol (EMBRAPA, 2013), medium texture, with the following physicochemical characteristics in the arable layer (0-0.2 m): 62\% sand; $29 \%$ clay; $9 \%$ silt; $\mathrm{pH}$ in $\mathrm{H}_{2} \mathrm{O}$ of $6.2 ; 17 \mathrm{~g} \mathrm{dm}^{-3}$ organic matter; $15 \mathrm{mg} \mathrm{dm}{ }^{-3} \mathrm{P}$ (Mehlich); $71 \%$ base saturation; $\mathrm{K}^{+} ; \mathrm{Ca}^{+2}, \mathrm{Mg}^{+2}, \mathrm{Al}^{+3}, \mathrm{H}^{+}+$

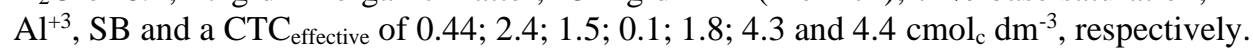

Standard seedlings of Eucalyptus urograndis clone VCC865 (E. urophylla x E. grandis hybrid), acquired in a certified nursery (Tecnoplant, Eunápolis/BA), approximately $30 \mathrm{~cm}$ high and three months old, were planted in $3.0 \times 2.0 \mathrm{~m}$ spacing, in previously prepared holes $(30 \times 30 \times 30 \mathrm{~cm})$ and fertilized with $22.5 \mathrm{~g}$ $\mathrm{P}_{2} \mathrm{O}_{5}$ (simple superphosphate), $1.1 \mathrm{~g}$ boron (borax) and $1.0 \mathrm{~g}$ zinc (zinc sulfate), according to the crop needs (BARROS; NOVAES, 1999). The plants were irrigated manually in a complementary manner, so that adequate water availability was maintained.

The treatments consisted of the pre-emergence application of the herbicides isoxaflutole $\left(\right.$ Fordor $^{\circledR}$ ), flumioxazin (Flumyzin $500^{\circledR}$ ) and sulfentrazone (Solara ${ }^{\circledR}$ ), to irrigation water twenty days after planting the eucalyptus seedlings. The herbicide doses used were: isoxaflutole $-0 ; 75 ; 105 ; 135$ and $165 \mathrm{~g} \mathrm{i.a.} \mathrm{ha}^{-1}$; flumioxazin - 0;70; 90; 110 and 130 g i.a. ha ${ }^{-1}$; and sulfentrazone - 0; 400;600; 800 and $1000 \mathrm{~g}$ i.a. ha $\mathrm{h}^{-1}$. At the time of application, the commercial herbicide product was dosed, diluted in five liters of water and applied manually with the aid of a conventional 5-L watering can directly on the plant (SP) or only on the soil (SS).

The experimental design used in each herbicide was a randomized block design, in a 5 x 2 factorial scheme, with four replications, considering as factors the five herbicide doses and the two forms of application 
(on the plant and on the soil). The experimental plots consisted of one seedling per planting hole, with a useful area of $0.8 \mathrm{~m}^{2}$ surrounding the plants of each plot.

The phytotoxicity of herbicides to eucalyptus plants was quantified by visual evaluation in relation to the control at 7, 14, 21, 28, 35, 42 and 60 days after application (DAA), with values from 0 to $100 \%$, as a function of symptom intensity, where $0 \%$ corresponded to the absence of visible symptoms and $100 \%$ to plant death (SBCPD, 1995).

At 60 DAA, eucalyptus plants were evaluated for height, stem diameter, Falker chlorophyll index, leaf number, total leaf area and shoot dry mass.

Plant height was obtained by measuring from the soil surface to the apical bud, with the aid of a graduated ruler. Stem diameter was measured with a digital caliper at $2 \mathrm{~cm}$ from the soil surface. Leaf area was determined using a LI-COR ${ }^{\circledR}$ Area Meter (LI-3100). Falker chlorophyll index was determined with a ClorofiLOG Falker ${ }^{\circledR}$ portable chlorophyll meter (CFL1030). For the obtention of dry mass, the plant shoot was harvested and packed in paper bags, placed in a greenhouse with forced air circulation for drying $\left(65 \pm 3{ }^{\circ} \mathrm{C}\right)$, until reaching a constant mass, and then weighed on a 0.01-g precision balance.

At the end of the experiment, at 60 DAA, identification was performed, based on specialized literature (LORENZI, 2008), and quantification of weeds located in the area surrounding eucalyptus plants. Thus, samples were taken in the useful area of the plots, totaling a sample area of $3.2 \mathrm{~m}^{2}$ per treatment. From the quantification of species, weed density (number of plants $\mathrm{m}^{-2}$ ) was determined in the sampled area and taken as a parameter to estimate the control effectiveness of the applied treatments.

Data were subjected to analysis of variance homogeneity (Bartlett's test) and normality (Lilliefors) and subsequently subjected to analysis of variance by the F test; the means were compared by the Tukey test $(\mathrm{p} \leq 0.05)$. For quantitative effects, polynomial regression analysis was performed, using the ASSISTAT statistical software, version 7.7 .

\section{RESULTS}

Among the herbicides tested, only sulfentrazone caused intoxication symptoms in eucalyptus plants in both forms of application (Figure 1A and 1B); while isoxaflutole and flumioxazin were selective to the eucalyptus crop at all evaluated doses, regardless of the application form.

The injuries resulting from sulfentrazone intoxication were observed from 7 days after application (DAA) and persisted until 42 DAA, with higher levels at 14, 21 and 28 DAA, reaching estimated mean percentages of 41,40 and $29 \%$, respectively (Figure 1A).
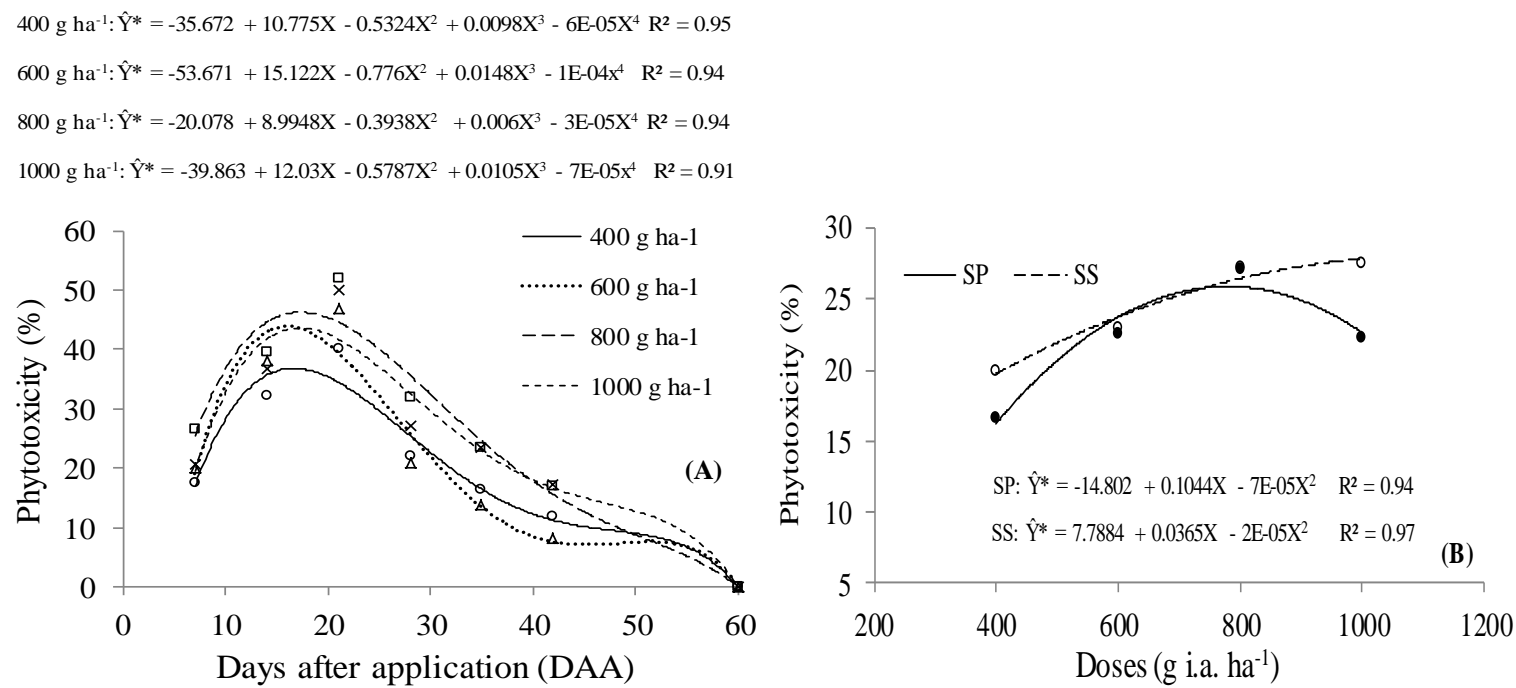

*Significant at $5 \%$ probability by regression analysis of variance.

Figura 1. Estimativa da fitotoxicidade em plantas de eucalipto, clone VCC865, aos 7, 14, 21, 28, 35, 42 e 60 dias após a aplicação (DAA) (A) de doses do herbicida sulfentrazone, via água de irrigação sobre a planta (SP) e sobre o solo (SS) (B) na fase de implantação da cultura.

Figure 1. Estimation of phytotoxicity in eucalyptus plants, clone VCC865, at 7, 14, 21, 28, 35, 42 and 60 days after application (DAA) (A) of sulfentrazone herbicide, via irrigation water on the plant (SP) and on the soil (SS) (B) in the crop implementation stage. 
At 14 and 21 DAA, sulfentrazone application at the highest doses (800 and $1000 \mathrm{~g}$ i.a. ha $\left.{ }^{-1}\right)$ resulted in more severe plant injuries, with mean phytotoxicity percentages of 44 and $41 \%$, respectively; when applied to the soil, the dose of $1000 \mathrm{~g}$ i.a. ha ${ }^{-1}$ led to a higher intoxication level than the application on plants (Figure 1B).

From 17 DAA, estimated period of maximum phytotoxicity, regardless of the dose applied, there was a tendency to reduce intoxication levels, showing signs of plant recovery, confirmed by the absence of symptoms at 60 DAA (Figure 1A), with the release of vigorous shoots and new leaf emissions that no longer showed symptoms of herbicide intoxication.

The main visual symptoms of sulfentrazone intoxication observed in the plants were: purplish young leaves, emission of leaves with smaller photosynthetic area and loss of apical dominance in some plants.

Regarding eucalyptus growth parameters, a significant effect was observed only for the herbicides isoxaflutole and flumioxazin $(\mathrm{p} \leq 0.05)$; while sulfentrazone, despite the injuries caused to plants, did not have significant influence on crop growth.

\section{Effect of isoxaflutole on the initial growth of eucalyptus plants}

For plants treated with isoxaflutole, a significant interaction was observed between herbicide dose $\mathrm{x}$ form of application only for the Falker chlorophyll index. For the other characteristics evaluated, there was a significant effect only of the applied doses of the herbicide $(\mathrm{p} \leq 0.05)$.

Plant height and stem diameter increased linearly with increasing doses of isoxaflutole, reaching increments of 17.5 and $16.3 \%$, respectively, when the highest tested dose $\left(165 \mathrm{~g}\right.$ i.a. ha $\left.{ }^{-1}\right)$ was applied in relation to the control with no herbicide application (Figures $2 \mathrm{~A}$ and $2 \mathrm{~B}$ ).
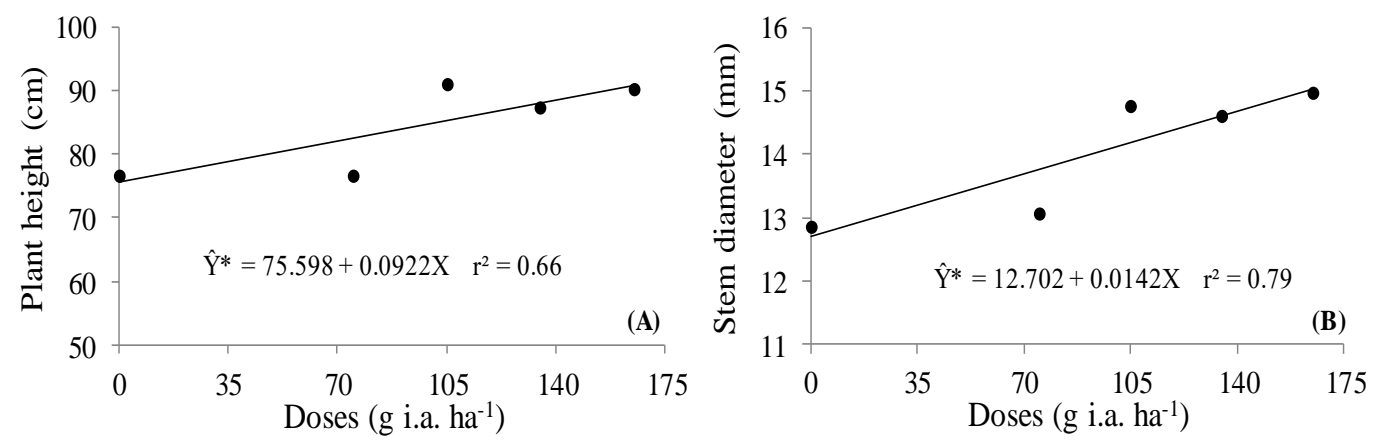

*Significant at $5 \%$ probability by regression analysis of variance.

Figura 2. Estimativa da altura de plantas (A) e diâmetro do caule (B) em eucalipto, clone VCC865, submetido a doses do herbicida isoxaflutole, aplicado via água de irrigação na fase de implantação da cultura.

Figure 2. Estimation of plant height (A) and stem diameter (B) in eucalyptus, clone VCC865, submitted to doses of the herbicide isoxaflutole, applied via irrigation water in the crop implementation stage.

The increase in the applied doses of isoxaflutole led to a linear increase in leaf number and leaf area of eucalyptus plants, with the highest results recorded at $165 \mathrm{~g}$ i.a. ha ${ }^{-1}$, which represents an increase of 60 and $76 \%$, respectively, when compared to the treatment without herbicide application (Figures 3A and 3B).
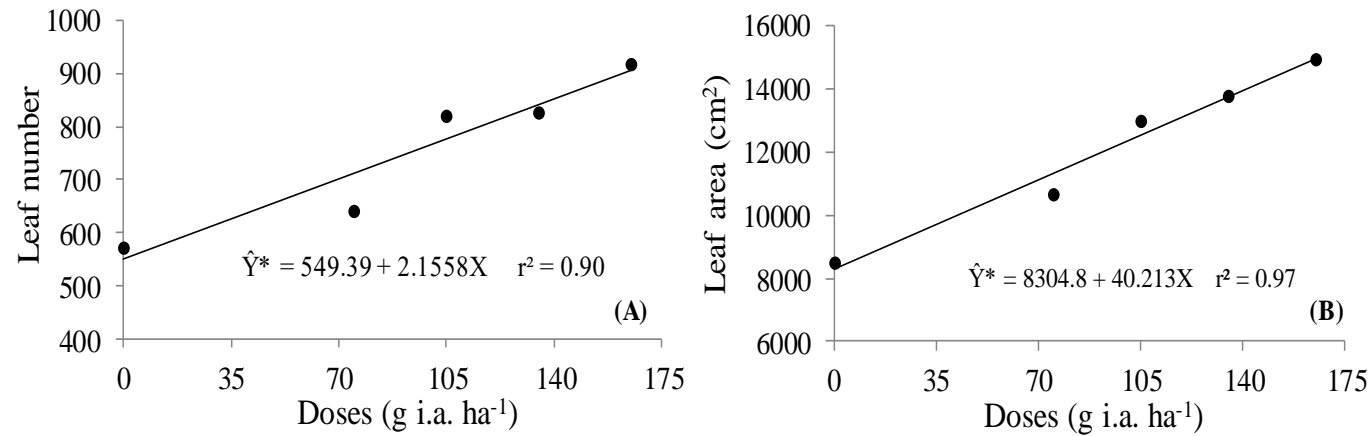

*Significant at $5 \%$ probability by regression analysis of variance.

Figura 3. Estimativa do número de folhas (A) e área foliar (B) de plantas de eucalipto, clone VCC865, submetidas a doses do herbicida isoxaflutole, aplicado via água de irrigação na fase de implantação da cultura.

Figure 3. Estimation of leaf number (A) and leaf area (B) of eucalyptus plants, clone VCC865, submitted to doses of the herbicide isoxaflutole, applied via irrigation water in the crop implementation stage. 
The Falker chlorophyll index, in both forms of application (SP and SS), showed a linear increase with increasing herbicide doses; higher results were recorded at $165 \mathrm{~g}$ i.a. ha ${ }^{-1}, 9.6$ and $6.4 \%$, respectively, higher than the control index. From the interaction unfolding analysis, it was found that there was no difference between forms of application (SP and SS), when evaluated within each single dose of isoxaflutole (Figure 4A).
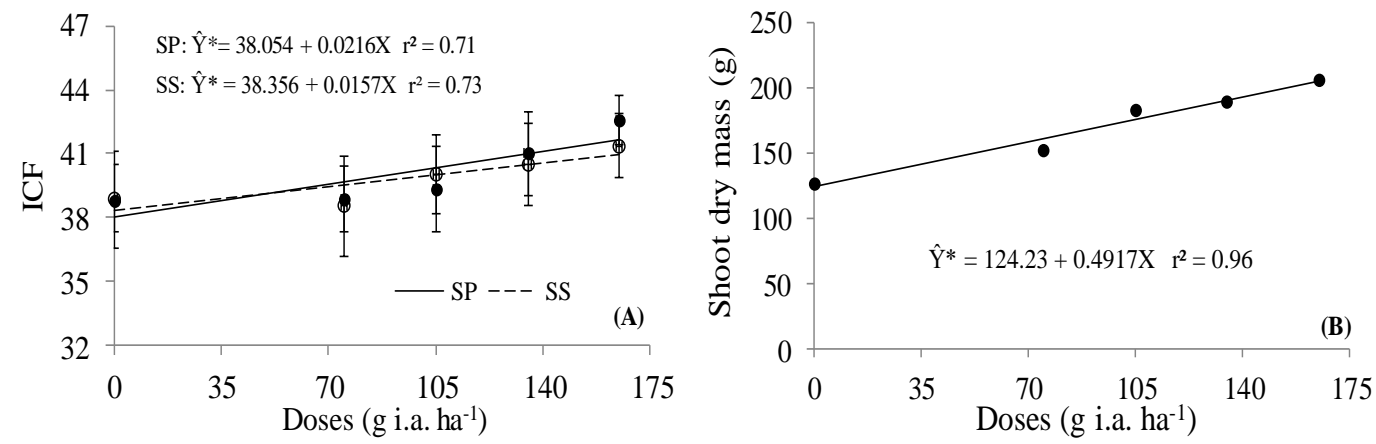

*Significant at $5 \%$ probability by regression analysis of variance.

Figura 4. Estimativa do índice de clorofila Falker (ICF) (A) e massa seca da parte aérea (B) de plantas de eucalipto, clone VCC865, submetidas a doses do herbicida isoxaflutole, aplicado via água de irrigação sobre a planta (SP) e sobre o solo (SS) na fase de implantação da cultura.

Figure 4. Estimation of the Falker chlorophyll index (ICF) (A) and shoot dry mass (B) of eucalyptus plants, clone VCC865, submitted to doses of the herbicide isoxaflutole, applied via irrigation water on the plant (SP) and on the soil (SS), in the crop implementation stage.

Shoot dry mass increased linearly as the applied doses of the herbicide were increased and thus reached a $62 \%$ increase at the highest tested dose, compared to the control (Figure 4B).

\section{Effect of flumioxazin on the initial growth of eucalyptus plants}

In the treatments with flumioxazin application, there was a significant interaction between herbicide dose and form of application for stem diameter, leaf area and shoot dry mass of eucalyptus plants. For the other characteristics evaluated, there was a significant effect only of the applied doses of the herbicide $(\mathrm{p} \leq 0.05)$, except for the Falker chlorophyll index, in which there was no significance of the analyzed factors.

Plant height increased as the herbicide doses increased, with an approximate increase of $8.0 \%$ at the highest dose, compared to the control (Figure 5A). For stem diameter, in both forms of application (SP and SS), although not significantly different within each single dose, this characteristic was linearly increased with flumioxazin increase, reaching $130 \mathrm{~g}$ i.a. $\mathrm{ha}^{-1}$, an increase of 22 and 19\%, respectively, in relation to the control (Figure 5B).
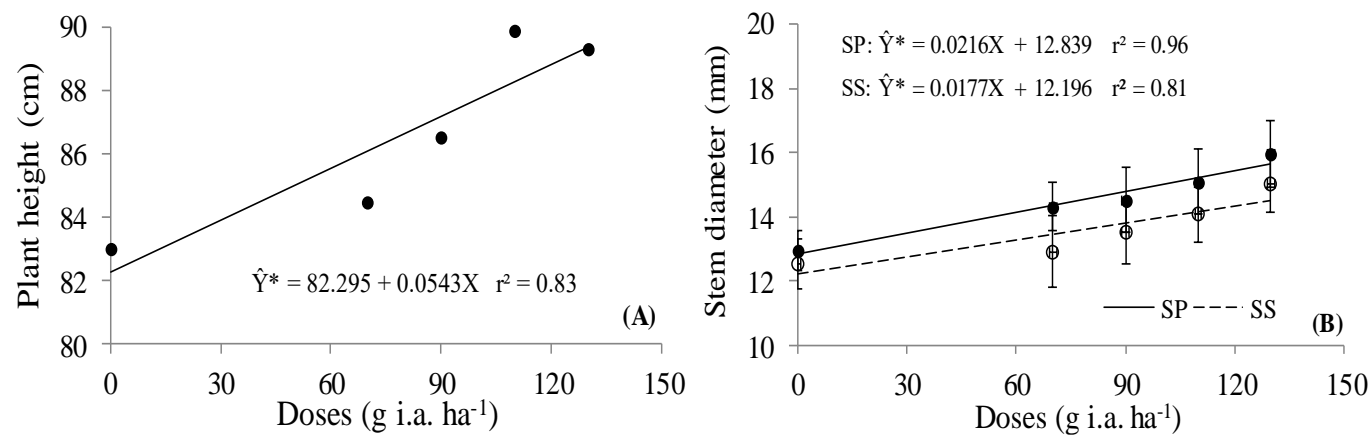

*Significant at $5 \%$ probability by regression analysis of variance.

Figura 5. Estimativa da altura de plantas (A) e diâmetro do caule (B) em eucalipto, clone VCC865, submetido a doses do herbicida flumioxazin, aplicado via água de irrigação sobre a planta (SP) e sobre o solo (SS) na fase de implantação da cultura.

Figure 5. Estimation of plant height (A) and stem diameter (B) in eucalyptus, clone VCC865, submitted to doses of the herbicide flumioxazin, applied via irrigation water on the plant (SP) and on the soil (SS), in the crop implementation stage.

Leaf number showed a linear increase as a function of flumioxazin doses; a higher result was obtained at the dose of $130 \mathrm{~g}$ i.a. $\mathrm{ha}^{-1}$, with a $34 \%$ increase, compared to the control without herbicide application (Figure

FLORESTA, Curitiba, PR, v. 50, n. 1, p. 1031 - 1040, jan/mar 2020.

Araujo Neto, A. C. et.al.

ISSN eletrônico 1982-4688 
6A). Regarding leaf area, for both forms of application (SP and SS), a linear increase was observed as flumioxazin doses were increased; at the highest dose tested, there was an increase of 95 and 44\%, respectively, when compared to the control (Figure 6B).
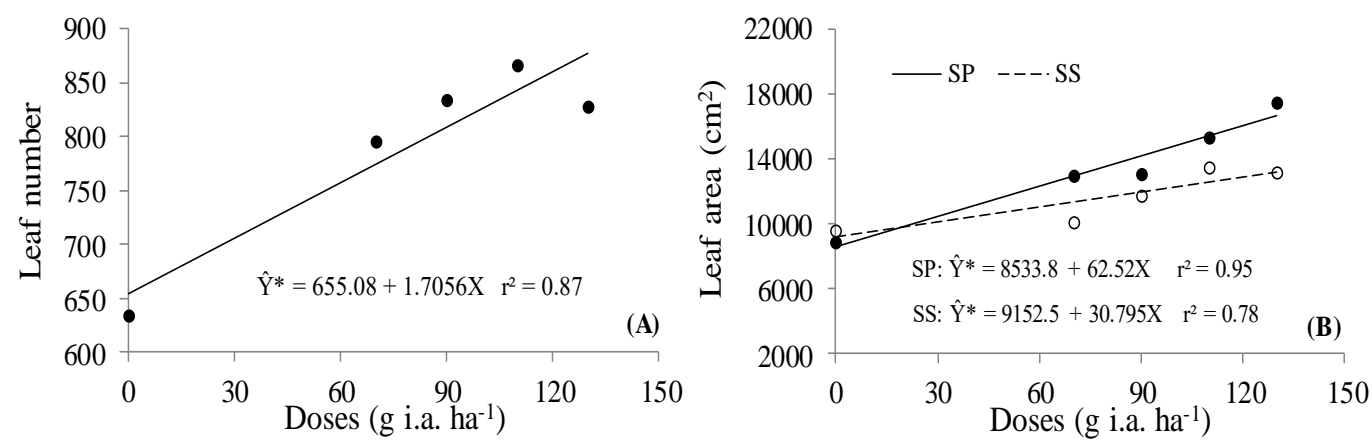

*Significant at $5 \%$ probability by regression analysis of variance.

Figura 6. Estimativa do número de folhas (A) e área foliar total (B) de plantas de eucalipto, clone VCC865, submetidas a doses do herbicida flumioxazin, aplicado via água de irrigação sobre a planta (SP) e sobre o solo (SS) na fase de implantação da cultura.

Figure 6. Estimation of leaf number (A) and total leaf area (B) of eucalyptus plants, clone VCC865, submitted to doses of the herbicide flumioxazin, applied via irrigation water on the plant (SP) and on the soil (SS), in the crop implementation stage.

The effects of herbicide on leaf area were more pronounced when the application was made directly on the plants (SP), leading to a significant increase at the dose of $130 \mathrm{~g}$ i.a. ha ${ }^{-1}$, surpassing in $33 \%$ the results obtained in the application only on the soil (SS) (Table 1).

Tabela 1. Área foliar total e massa seca da parte aérea de plantas de eucalipto, clone VCC865, em função das formas de aplicação de doses do herbicida flumioxazin.

Table 1. Total leaf area and shoot dry mass of eucalyptus plants, clone VCC865, as a function of forms of application of flumioxazin doses.

\begin{tabular}{|c|c|c|c|c|c|}
\hline \multirow{2}{*}{$\begin{array}{l}\text { Forms of } \\
\text { application }\end{array}$} & \multicolumn{5}{|c|}{ Doses (g i.a. ha' ${ }^{-1}$ ) } \\
\hline & 0 & 70 & 90 & 110 & 130 \\
\hline & \multicolumn{5}{|c|}{ Total leaf area $\left(\mathrm{cm}^{2}\right)$} \\
\hline SP & $8856.16 \mathrm{a}^{1}$ & $12998.53 \mathrm{a}$ & $13037.98 \mathrm{a}$ & $15295.96 \mathrm{a}$ & $17488.34 \mathrm{a}$ \\
\hline \multirow[t]{2}{*}{ SS } & $9633.85 \mathrm{a}$ & $10087.75 \mathrm{a}$ & $11701.42 \mathrm{a}$ & $13516.86 \mathrm{a}$ & $13140.22 \mathrm{~b}$ \\
\hline & \multicolumn{5}{|c|}{ Shoot dry mass (g) } \\
\hline SP & $132.54 \mathrm{a}$ & $181.71 \mathrm{a}$ & $184.87 \mathrm{a}$ & $207.15 \mathrm{a}$ & $231.14 \mathrm{a}$ \\
\hline SS & $134.35 \mathrm{a}$ & $141.03 \mathrm{a}$ & $159.13 \mathrm{a}$ & $179.64 \mathrm{a}$ & $183.79 \mathrm{~b}$ \\
\hline
\end{tabular}

${ }^{1}$ Means followed by the same letter in the column do not differ by the Tukey test at $5 \%$ probability. ${ }^{2}$ Forms of application: on the plant (SP) or on the soil (SS).

In both forms of application (SP and SS), the increase in herbicide dose led to a linear increase in the dry mass of eucalyptus shoots and reached, at the highest tested dose, an increase of 71 and $36 \%$, respectively, in relation to the control (Figure 7).

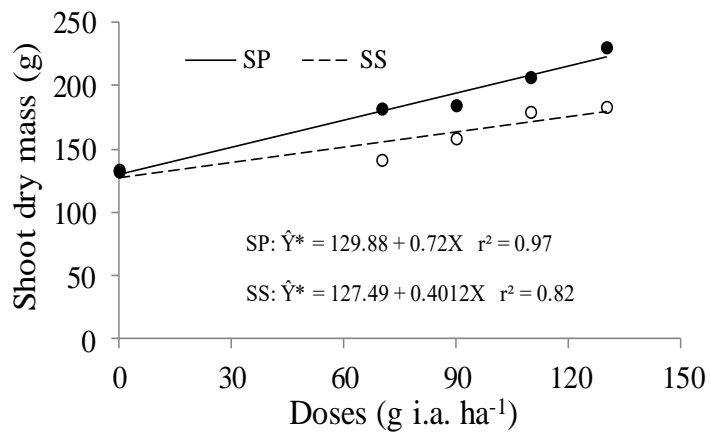

*Significant at $5 \%$ probability by regression analysis of variance. 
Figura 7. Estimativa da massa seca da parte aérea de plantas de eucalipto, clone VCC865, submetidas a doses do herbicida flumioxazin, aplicado via água de irrigação sobre a planta (SP) e sobre o solo (SS) na fase de implantação da cultura.

Figure 7. Estimation of shoot dry mass of eucalyptus plants, clone VCC865, submitted to doses of the herbicide flumioxazin, applied via irrigation water on the plant (SP) and on the soil (SS), in the crop implementation stage.

In the evaluation of the application forms within each single dose of flumioxazin, it was verified that the dose of $130 \mathrm{~g}$ i.a. ha ${ }^{-1}$, when applied directly to the plants (SP), led to a significant increase in eucalyptus shoot dry mass, with values $25 \%$ higher than those obtained for application only on the soil (SS) (Table 1).

\section{Efficiency of herbicide application in weed control}

In the survey of the weed community, 27 weed species were identified, distributed in 23 genera and 11 botanical families, with predominance of dicotyledonous, which were $81.5 \%$ of the composition. In the samplings, 1,841 individuals were quantified, and $75 \%$ of this total were registered in treatments without herbicide application (control). The most common species in the experimental area were Chenopodium carinatum (19.82\% in relation to the total number of individuals), Blainvillea biaristata (19.44\%), Urochloa decumbens (18.61\%), Portulaca oleracea (9.61\%) and Eleusine indica $(6.95 \%)$.

Regarding weed density, it was found that for none of the herbicides analyzed there was a significant effect of the forms of application (SP and SS), only of the doses tested. In the treatments without herbicide application (control), high weed densities were verified in the areas around the planting holes, with values ranging between 290 and 360 plants $\mathrm{m}^{-2}$ (Figure 8). A proportional decrease in plant population was observed with increasing sulfentrazone doses, reaching values below 60 plants $\mathrm{m}^{-2}$ when 400 and $600 \mathrm{~g}$ i.a. ha ${ }^{-1}$ and 10 plants $\mathrm{m}^{-2}$ at 800 and $1000 \mathrm{~g}$ i.a. ha ${ }^{-1}$ were used, representing an average reduction of 85.0 and $98.2 \%$, respectively, in relation to the control (Figure $8 \mathrm{~A}$ ). The same tendency to reduce weed density was observed with the application of the herbicides isoxaflutole and flumioxazin (Figure 8B).
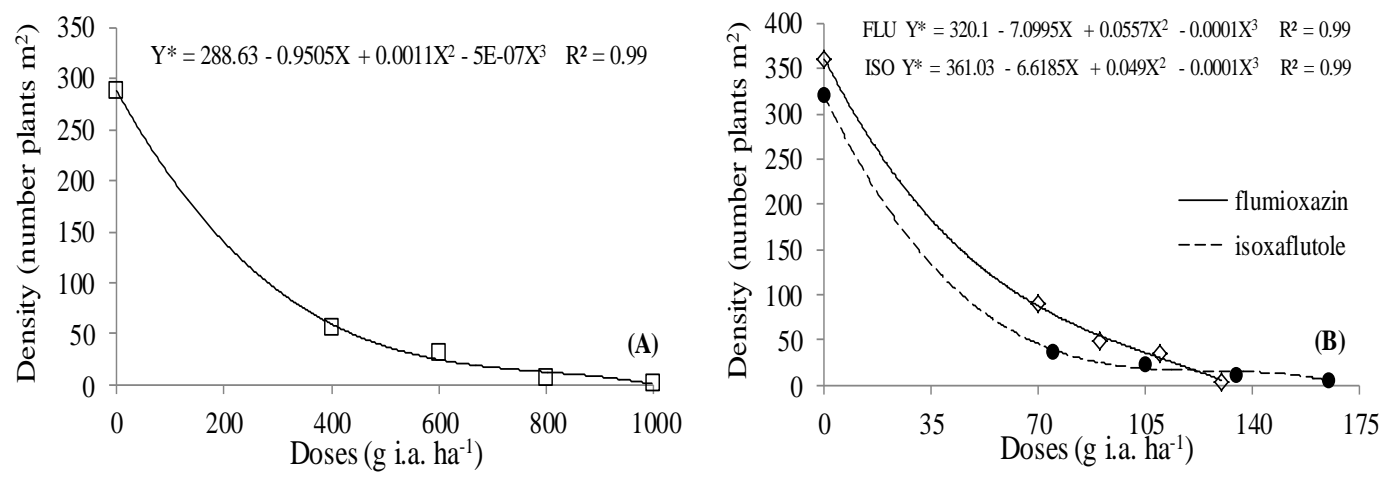

*Significant at $5 \%$ probability by regression analysis of variance.

Figura 8. Estimativa da densidade de plantas daninhas em função de doses dos herbicidas sulfentrazone (A), isoxaflutole e flumioxazin (B), aplicados via água de irrigação na fase de implantação da cultura do eucalipto, clone VCC865.

Figure 8. Estimation of weed density as a function of doses of herbicides sulfentrazone (A), isoxaflutole and flumioxazin (B) applied via irrigation water during the implementation stage of the eucalyptus crop, clone VCC865.

For isoxaflutole, mean control percentages were around 90 and $97 \%$ when the lowest 75 and 105 g i.a. $\mathrm{ha}^{-1}$ ) and the highest doses (135 and $165 \mathrm{~g}$ i.a. ha ${ }^{-1}$ ) were applied, respectively, in relation to the control. While

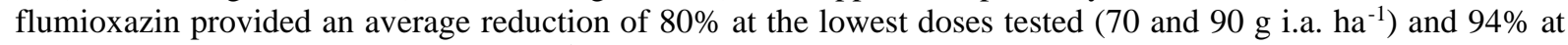

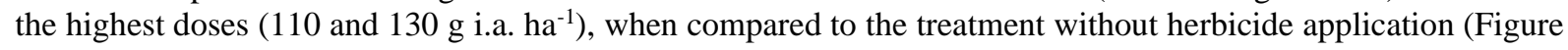
$8 \mathrm{~B})$.

\section{DISCUSSION}

The highest degree of intoxication caused by the application of the herbicide sulfentrazone at the dose of $1000 \mathrm{~g}$ i.a. ha ${ }^{-1}$, when performed directly on the soil, in relation to the application on plants (Figure 1B), is probably due to the fact that sulfentrazone is absorbed by plants through roots and leaves, with limited movement in phloem as a function of rapid leaf desiccation (RODRIGUES; ALMEIDA, 2011). Thus, it can be

FLORESTA, Curitiba, PR, v. 50, n. 1, p. 1031 - 1040, jan/mar 2020.

Araujo Neto, A. C. et.al.

ISSN eletrônico 1982-4688

DOI: $10.5380 /$ rf.v50 i1.60839 
inferred that, at higher doses, the absorption of this herbicide occurs more strongly through the roots of eucalyptus plants, suggesting more severe effects on applications directly to the soil. According to Melo et al. (2010), when the herbicide is applied at pre-emergence in the soil, it can suffer sorption, leaching and/or degradation by physical, chemical and biological processes, besides being absorbed by weeds and/or cultivated plants.

The reducing trend in intoxication levels by sulfentrazone application, showing recovery signs of eucalyptus plants from 17 DAA (Figure 1A), was also observed by Tiburcio et al. (2012), who found that, from 30 DAA, eucalyptus plants (E. grandis, clone CRV1189) treated with sulfentrazone $\left(500 \mathrm{~g}\right.$ i.a. ha $\left.{ }^{-1}\right)$ had less than $10 \%$ intoxication, showing recovery. However, Carbonari et al. (2012) observed that sulfentrazone intoxication symptoms (400 and $600 \mathrm{~g}$ i.a. ha $^{-1}$ ) persisted until 77 days after application to eucalyptus (E. urograndis) clones. These authors also reported that the concentrations of sulfentrazone absorbed by the plants were proportional to dry mass reduction, indicating that the variations in the selectivity of eucalyptus clones may be related to differentiated herbicide absorption.

The visual symptoms of sulfentrazone intoxication observed in eucalyptus plants (purplish young leaves, emission of leaves with smaller photosynthetic area and loss of apical dominance) are similar to those described by Takahashi et al. (2009), who reported that sulfentrazone symptoms began on the seventh day after application in $E$. urograndis clones. Velini et al. (2005) state that sulfentrazone may be toxic to eucalyptus and that young leaves formed between planting and application show greater sensitivity to the product, which allows the emergence of very sharp lesions.

Despite the injuries caused to eucalyptus plants, sulfentrazone had no influence on initial crop growth, showing tolerance of clone VCC865 to this herbicide when applied via irrigation water. Vaughn and Duke (1991) state that the main factor for the tolerance of some plants to sulfentrazone seems to be the differential metabolism, besides the limited movement of this herbicide from the application site to the action site, the molecular modifications of this site and the rapid metabolization. On the other hand, the application of isoxaflutole and flumioxazin significantly affected the growth characteristics of eucalyptus.

\section{Effect of isoxaflutole on the initial growth of eucalyptus plants}

The increase in eucalyptus growth parameters as the applied doses of isoxaflutole increased in relation to the control, demonstrates the selectivity of this herbicide to the crop when applied to irrigation water, regardless of form of application, favoring the initial plant growth. Similarly, by evaluating the selectivity of E. globulus and E. saligna genotypes to herbicide doses, Agostinetto et al. (2010) concluded that isoxaflutole, applied in conventional spraying system, was the most selective to the crop at doses up to $150 \mathrm{~g}$ i.a. $\mathrm{ha}^{-1}$.

The gains observed, mainly in leaf number, leaf area and dry mass of eucalyptus shoots when the highest dose of isoxaflutole ( $165 \mathrm{~g}$ i.a. $\mathrm{ha}^{-1}$ ) is applied, may be due to the efficient weed control promoted at this dose during the experimental period, resulting in higher initial crop growth, evidenced by the significant increase in the photosynthetic area of the plants, corresponding to approximately 345 leaves and $6439 \mathrm{~cm}^{2}$, when compared to the treatment without application. Silva et al. (2014) report that isoxaflutole has residual effect on the soil, according to the dosage used, which allows the efficient control of weeds such as Brachiaria decumbens and Panicum maximum, preventing new flows of these plants.

In agreement with the results obtained, Brighenti and Muller (2014) found in African mahogany (Khaya ivorensis) that, despite being the most phytotoxic among the herbicides tested (imazapyr, oxyfluorfen, chlorimuronethyl, imazethapyr, nicosulfuron), isoxaflutole sprayed at 75 and 112.5 g i.a. ha ${ }^{-1}$ resulted in a 33 and $50 \%$ increase, respectively, in the number of plant leaves, evaluated at 28 days after application. On the other hand, in Australian cedar (Toona ciliata), these authors found significant reductions in total dry mass and leaf area of plants due to isoxaflutole phytotoxicity (75 and $112.5 \mathrm{~g}$ i.a. ha ${ }^{-1}$ ) at 28 days after application, as compared to the control.

Although the forms of application of isoxaflutole, when applied to irrigation water, did not influence the initial growth of eucalyptus in this study, Carbonari et al. (2010) evaluated the effectiveness of aerial application of isoxaflutole (150 and $225 \mathrm{~g}$ i.a. ha ${ }^{-1}$ ), when applied to clay granules, and found satisfactory levels of weed control for Ipomoea grandifolia, Merremia cissoides, Panicum maximum and Urochloa decumbens, at 110 DAA, indicating gains in extension in the period of residual effect of the herbicide, compared to the conventional spraying system.

\section{Effect of flumioxazin on the initial growth of eucalyptus plants}

The increase in eucalyptus growth characteristics, mainly in leaf number, leaf area and shoot dry mass, as a result of the increased doses of flumioxazin, demonstrates the selectivity of this herbicide to the crop, regardless of its form of application and, associated with the efficient pre-emergence weed control observed during the experimental period, may have contributed to the greater use of environmental resources by eucalyptus plants and, consequently, higher initial crop growth.

In agreement with with these results, Tiburcio et al. (2012) concluded that flumioxazin, applied in a spray system, is selective to eucalyptus (E. grandis, clone CRV1189), since the height and stem diameter of plants treated with this herbicide at doses of 75, 100 and $125 \mathrm{~g}$ i.a. ha ${ }^{-1}$ did not differ from the weeded control at 90 days after application. However, Inoue et al. (2014) found under field conditions, at 35 days after application, a significant 
reduction in height and stem diameter of flumioxazin-sprayed Jatropha curcas $\left(30 \mathrm{~g}\right.$ i.a. ha $\left.\mathrm{h}^{-1}\right)$ in relation to controls with and without weed management.

The highest leaf development observed in plants treated with the highest dose of flumioxazin ( $130 \mathrm{~g}$ i.a. ha $\left.\mathrm{h}^{-1}\right)$, with significant average gains in number and photosynthetic area of approximately 230 leaves and $6000 \mathrm{~cm}^{2}$, respectively, in relation to the the control, shows the selectivity of this herbicide to the crop and suggests its effectiveness in pre-emergence weed control when irrigated. The lowest leaf emission by eucalyptus, verified in the treatment without flumioxazin application, is probably due to the stress imposed by the competition, and can compromise seedling survival in the field or generate substantial yield losses, by reducing the photosynthetic apparatus of the plants.

The increases in leaf area and dry mass of eucalyptus shoots obtained from flumioxazin application $(130 \mathrm{~g}$ i.a. ha $^{-1}$ ) directly on plants (SP), compared to the application only on soil (SS), prove the selectivity of this herbicide, when applied via irrigation water, which ensures greater practical applicability of this form of application and beneficial effects on the initial growth of eucalyptus, thus presenting potential for large-scale use in the implementation phase of commercial eucalyptus plantations. However, in a study conducted with 'Mundo Novo' coffee (Coffea arabica L.) seedlings, Silva et al. (2017) found phytotoxic effects resulting from the action of the herbicide flumioxazin, when sprayed directly on the plants, causing significant reductions in their growth, suppressing up to $11 \%$ stem diameter and $22 \%$ shoot dry mass, at the highest dose tested $\left(200 \mathrm{~g}^{\mathrm{i} . \mathrm{a}}\right.$. ha $\left.\mathrm{h}^{-1}\right)$, relative to the control without application.

\section{Efficiency of herbicide application in weed control}

The occurrence of high weed densities in treatments without herbicide application (control) shows the importance of control methods as a way to reduce the degree of weed infestation in eucalyptus plantations, thus avoiding negative effects on initial crop development, as a result of competition for environmental resources.

Despite the phytotoxic effects caused to the crop, sulfentrazone let to efficient weed control when applied via irrigation water, and the percentage of population reduction was proportional to the increase in the applied doses. The same tendency was observed for application via irrigation water of herbicides isoxaflutole and flumioxazin which, regardless of form of application (SP or SS), yielded effective weed control in the region surrounding the planting holes at the highest doses (165 and $130 \mathrm{~g}$ i.a., respectively), favoring the increase in the initial growth of eucalyptus plants, mainly leaf number, leaf area and shoot dry mass. These results corroborate the selectivity of these herbicides to eucalyptus plants when applied at pre-emergence via irrigation water, as well as their beneficial effects on crop implementation phase by the efficient control of the weed community.

\section{CONCLUSIONS}

- The herbicides sulfentrazone, isoxaflutole and flumioxazin, applied via irrigation water, regardless of form of application, were selective to the eucalyptus crop, clone VCC865, at the tested doses.

- Despite causing injuries to eucalyptus plants persistent up to 42 DAA, sulfentrazone applied via irrigation water did not interfere with crop growth; however, it yielded an efficient weed control.

- Application via irrigation water of herbicides isoxaflutole, regardless of form of application, and flumioxazin, applied directly to the plants, at the highest doses studied (165 and $130 \mathrm{~g}$ i.a. ha ${ }^{-1}$, respectively), favored the initial growth of eucalyptus plants, mainly increasing leaf number, leaf area and dry mass accumulation.

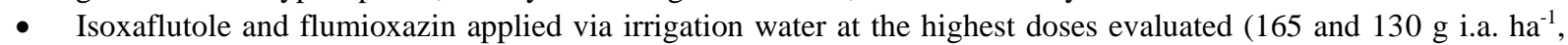
respectively), regardless of form of application, led to an effective weed control around eucalyptus planting holes.

\section{REFERENCES}

AGostinetTo, D.; TARouCO, C. P.; MARKus, C.; OliVEIRA, E.; SILVA, J. M. B. V.; TIRONI, S. P. Seletividade de genótipos de eucalipto a doses de herbicidas. Semina: Ciências Agrárias, Londrina, v. 31, n. 3, p. 585-598, 2010.

BARROS, N. F.; NOVAIS, R. F. Eucalipto. In: RIBEIRO, A. C.; GUIMARÃES, P. T. G.; ALVAREZ, V. H. (Org.). Recomendação para o uso de corretivos e fertilizantes em Minas Gerais: $5^{\text {a }}$ aproximação. Viçosa, MG: UFV, p. 303-305, 1999.

BARROS, R. E.; TUFFI SANTOS, L. D.; CRUZ, L. R; FARIA, R. M.; COSTA, C. A.; FELIX, R. C. Physiological response of eucalyptus species grown in soil treated with Auxin-Mimetic herbicides. Planta Daninha, Viçosa, v. 32, n. 3, p. 629-638, 2014.

BRIGHENTI, A. M.; MULlER, M. D. Tolerância de plantas de Khaya ivorensis e Toona ciliata a herbicidas. Floresta, Curitiba, v. 44, n. 4, p. 747-754, 2014.

CARBONARI, C. A.; VELINI, E. D.; GOMES, G. L. G. C.; TAKAHASHI, E. N.; ARALDI, R. Seletividade e absorção radicular do sulfentrazone em clones de eucalipto. Planta Daninha, Viçosa, v. 30, n. 1, p. 147-153, 2012. 
CARBONARI, C. A.; VELINI, E. D.; SILVA, J. R. M.; BENTIVENHA, S. R. P.; TAKAHASHI, E. N. Eficácia da utilização de grânulos de argila como veículo para a aplicação aérea de sulfentrazone e isoxaflutole em área de implantação de eucalipto. Planta Daninha, Viçosa, v. 28, n. 1, p. 207-212, 2010.

COSTA, A. C. P. R.; COSTA, N. V.; PEREIRA, M. R. R.; MARTINS, D. Efeito da deriva simulada de glyphosate em diferentes partes da planta de Eucalyptus grandis. Semina: Ciências Agrárias, Londrina, v.33, n.5, p.1663-1672, 2012.

EMPRESA BRASILEIRA DE PESQUISA AGROPECUÁRIA - EMBRAPA. Sistema Brasileiro de Classificação de Solos. Brasília: Embrapa Solos, 2013. 353 p.

FERRAÇO, M.; PIRES, F. R.; BELO, A. F.; CELIN FILHO, A.; BONOMO, R. Efeito da densidade populacional de Canavalia ensiformis na fitorremediação de solo contaminado com sulfentrazone. Revista Ciência Agronômica, Fortaleza, v. 48, n. 1, p. 32-40, 2017.

INSTITUTO NACIONAL DE METEREOLOGIA - INMET. Dados meteorológicos entre outubro/2016 e janeiro/2017. Disponível em: 〈http://www.inmet.gov.br/portal/index.php?r=bdmep/bdmep>. Acesso em: 03 de março de 2017.

INDÚSTRIA BRASILEIRA DE ÁRVORES - IBÁ. Relatório anual IBÁ 2017: ano base 2016. Disponível em: <http://iba.org/images/shared/Biblioteca/IBA_RelatorioAnual2017.pdf>. Acesso em: 01/11/2017.

INOUE, M. H.; PEREIRA, K. M.; MENDES, K. F.; SANTOS, E. G.; DALlACORT, R.; POSSAMAI, A. C. S. Seletividade de herbicidas para pinhão manso em condições de casa de vegetação e campo. Bioscience Journal, Uberlândia, v. 30, supl. 2, p. 791-801, 2014.

LORENZI, H. Plantas daninhas do Brasil: terrestres, aquáticas, parasitas e tóxicas. 4. ed. Nova Odessa: Plantarum, 2008. $640 \mathrm{p}$.

MELO, C. A. D.; MEDEIROS, W. N.; TUFFI SANTOS, L. D.; FERREIRA, F. A.; TIBURCIO, R. A. S.; FERREIRA, L. R. Lixiviação de sulfentrazone, isoxaflutole e oxyfluorfen no perfil de três solos. Planta Daninha, Viçosa, v. 28, p. 385-392, 2010.

PEREIRA, F. C. M.; YAMAUTI, M. S.; ALVES, P. L. C. A. Interação entre manejo de plantas daninhas e adubação de cobertura no crescimento inicial de Eucalyptus grandis x E. urophylla. Revista Árvore, Viçosa, v. 36, n. 5, p. 941 949, 2012.

RODRIGUES, B. N.; ALMEIDA, F. S. Guia de herbicidas. 6. ed. Londrina: IAPAR, 2011. 697 p.

SILVA, A. A.; SILVA, J. F. Tópicos em manejo de plantas daninhas. Viçosa, MG: UFV, 2007. 367 p.

SILVA, B. P.; MACHADO, A. A.; FONSECA, E. D.; FERREIRA, M. C. Distribuição, diâmetro de gotas e fitoxicidade de herbicidas aplicados em mudas de eucalipto com pontas de indução de ar. Revista Brasileira de Herbicidas, Londrina, v. 13, n. 3, p. 225-234, 2014.

SILVA, L. G.; CASTANHEIRA, D. T.; VOLTOLINI, G. B.; SOUZA, I. F.; GONÇALVES, A. H.; GUIMARÃES, R. J. Sintomas de fitotoxicidade e crescimento de mudas de café submetidas aos herbicidas inibidores da PROTOX. Coffee Science, Lavras, v. 12, n. 3, p. 290-296, 2017.

SIMÕES, D.; SILVA, M. R. Desempenho operacional e custos de um trator na irrigação pós-plantio de eucalipto em campo. Revista Ceres, Viçosa, v. 59, n. 2, p. 164-170, 2012.

SOCIEDADE BRASILEIRA DA CIÊNCIA DAS PLANTAS DANINHAS - SBCPD. Procedimentos para instalação, avaliação e análise de experimentos com herbicidas. Londrina: SBCPD, 1995. 42 p.

TAKAHASHI, E. N.; ALVES, P. L. C. A.; SALGADO, T. P.; FARIAS, M. A.; SILVA, A. C.; BIAGGIONI, B. T. Consequências da deriva de clomazone e sulfentrazone em clones de E. grandis x E. urophylla. Revista Árvore, Viçosa, v. 33, n. 4, p. 685-683, 2009.

TIBURCIO, R. A. S.; FERREIRA, F. A.; FERREIRA, L. R.; MACHADO, M. S.; MACHADO, A. F. L. Controle de plantas daninhas e seletividade do flumioxazin para eucalipto. Cerne, Lavras, v. 18, n. 4, p. 523-531, 2012.

VAUGHN, K. C.; DUKE, S. O. Mechanisms of resistance. In: EBING, W. Chemistry of plant protection. New York: Springer-Verlag, p. 142-169, 1991.

VELINI, E. D.; TRINDADE, M. L. B.; ALVES, E.; CATÂNEO, A. C.; MARINO, C. L. MAIA, I. G.; MORI, E. S.; FURTADO, E. L.; GUERRINI, I. A.; WILCKEN, C. F. Eucalyptus ESTs corresponding to the protoporphyrinogen IX oxidase enzyme related to the synthesis of heme, chlorophyll, and to the action of herbicides. Genetics and Molecular Biology, Ribeirão Preto, v. 28, n. 3, p. 548-554, 2005. 